U.S. Department of the Interior

U.S. Geological Survey

\title{
Comparison of Hydrologic Data from Monroe County, Michigan, 1991-2001
}

Open-File Report 01-498

Prepared in cooperation with

Michigan Department of Environmental Quality

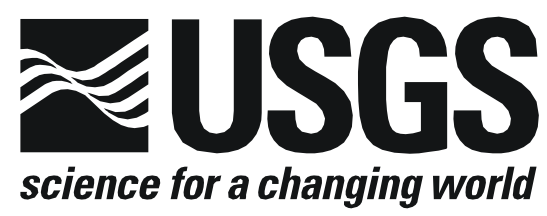




\section{Comparison of Hydrologic Data from Monroe County, Michigan, 1991-2001}

By J.R. Nicholas, S.P. Blumer, and R.M. McGowan

U.S. Geological Survey

Open-File Report 01-498

Lansing, Michigan

2001 


\section{U.S. DEPARTMENT OF THE INTERIOR}

Gale A. Norton, Secretary

\section{U.S. GEOLOGICAL SURVEY}

Charles G. Groat, Director

For additional information write:

District Chief

U.S. Geological Survey

6520 Mercantile Way, Ste. 5

Lansing, MI 48911-5991
Copies of this report can be purchased from: U.S. Geological Survey

Branch of Information Services

Box 25286

Denver, CO 80225-0286 


\section{CONTENTS}

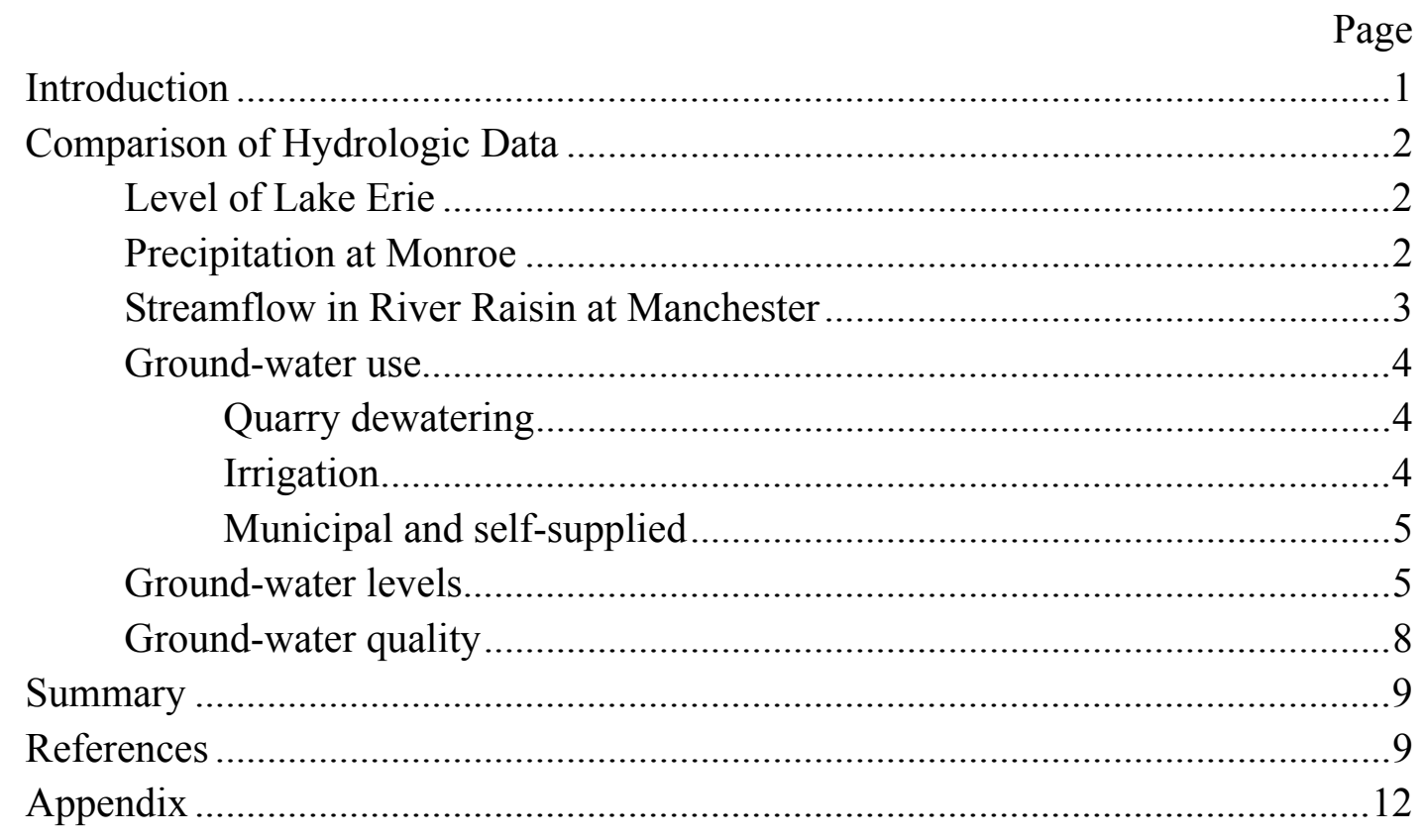

\section{FIGURES}

Figure 1. Graph showing level of Lake Erie, 1991-2000 ..................................2

Figure 2. Graph showing precipitation at city of Monroe, 1991-2000..................3

Figure 3. Graph showing seven-day minimum flows in the River Raisin at Manchester, 1991-2000 ......................................................3

Figure 4. Graph showing estimated ground-water use in 2000 ...........................4

Figure 5. Map showing location of observation wells and active quarries and bar graph showing change in depth to water from 1991-2001....

Figure 6. Graph showing changes in water levels in USGS observation wells, initial measurement through 2001 ......................................... 7

Figure 7. Hydrograph for well GLTO, 1979-2001 .............................................7

Figure 8. Hydrographs for wells GLTO and G7, November 27 to December 20, 2001

\section{TABLE}

Table 1. Chemical and physical characteristics of ground water in Monroe County, 1991-92 and 2001 


\title{
Comparison of Hydrologic Data from Monroe County, Michigan, 1991-2001
}

\author{
By J.R. Nicholas, S. P. Blumer, and R.M. McGowan
}

\section{INTRODUCTION}

In the summer of 2001, there were renewed concerns about the effects of quarry dewatering on nearby domestic ground-water supplies in Monroe County, Michigan. Reports of domestic wells "going dry" are not uncommon historically in Monroe County. Such reports have been linked to droughts, nearby irrigation, quarrying, and other large ground-water uses since as early as 1900 (Sherzer, 1900). Concerns about ground-water availability during the short, but extreme, drought of 1988 prompted the County and the State of Michigan to cooperate with the USGS (U.S.

Geological Survey) on a county water resources assessment during the early 1990s (Nicholas and others, 1996).

Aquifers in Monroe County generally yield sufficient water for domestic supplies. High transmissivities and low storage in fractured carbonate aquifers and poor water quality at depth (Nicholas and others, 1996), however, make domestic supplies very susceptible to the effects of drought and large withdrawals. Therefore, there are legitimate concerns about sustainable groundwater supplies in the County.

Additionally, significant increases in ground-water uses in Monroe County during the past decade coincide with very dry years during the late 1990s. Although ground-water-level data were collected by Monroe County during the last decade, there are not comparable data sets available for many water uses. Therefore, determining whether concerns about domestic wells going dry can be linked to ground-water withdrawals or climate is problematic.

In response to recent concerns, the USGS and MDEQ (Michigan Department of Environmental Quality) entered into a cooperative agreement in October 2001 to conduct a study regarding the availability of ground water in Monroe County. The major goal of this study is to determine how widespread are the impacts of quarry dewatering operations.

This report summarizes the initial phase of the study which consists of a comparison of hydrologic data from 1991 to 2001 . The 1991 data are reported by the USGS in the report by Nicholas and others (1996). Later data come from a variety of sources including USGS, MDEQ, Monroe County, National Oceanic and Atmospheric Administration, U.S. Army Corps of Engineers, and ground-water users. All non-USGS data in this report are given as reported; data verification was not a part of this initial phase. The types of data chosen for comparison in this report include water levels of Lake Erie, precipitation at Monroe, streamflow in the River Raisin at Manchester, ground-water use, ground-water levels, and ground-water quality.

The authors acknowledge the cooperation and provision of data and information by several agencies. Ground-water use for irrigation was provided by Ron Van Til of MDEQ. Quarry discharges were provided by Jennifer Rogers of MDEQ. Ground-water-level data for 1993 to 2001 were provided by the Monroe County Health Department. The authors also acknowledge Carlos Hernandez, Chris Hoard, Tom Morgan, Tom Sabin, and Dave Westjohn for collecting streamflow, ground-water, and ground-water-quality data in autumn, 2001. Sharon Baltusis and Jaye Lunsford assisted in the compilation and presentation of hydrologic data in this report. 


\section{COMPARISON OF HYDROLOGIC DATA}

The principal goal of comparing hydrologic data in this report is to support evaluation of whether ground-water-level declines are due to climate (dry years) or withdrawals. Water levels in Lake Erie, precipitation at Monroe, and streamflow in River Raisin at Manchester are data that should reflect general climate trends. Although streamflow is gaged in the River Raisin near Monroe, these data are not presented because irrigation withdrawals from the River Raisin in Monroe County may make the streamflow data unrepresentative of climate trends. Ground-water use, levels, and quality are data that should reflect the impact of withdrawals. Ground-water uses discussed in this report include quarry dewatering, municipal supply, and irrigation. Groundwater quality was evaluated because of the potential for poor quality water to migrate upward into wells in response to large ground-water withdrawals.

\section{Level of Lake Erie}

The level of Lake Erie did not have an upward or downward trend from 1991 to 2000 (fig. 1). The average annual level was above the long-term 80 -year average of 571.3 feet for 8 years and below average for 2 years (U.S. Army Corps of Engineers, written communication, 2001). From 1997 to 2000, levels declined every year; the last 2 years were below Data for 2001 are not available.

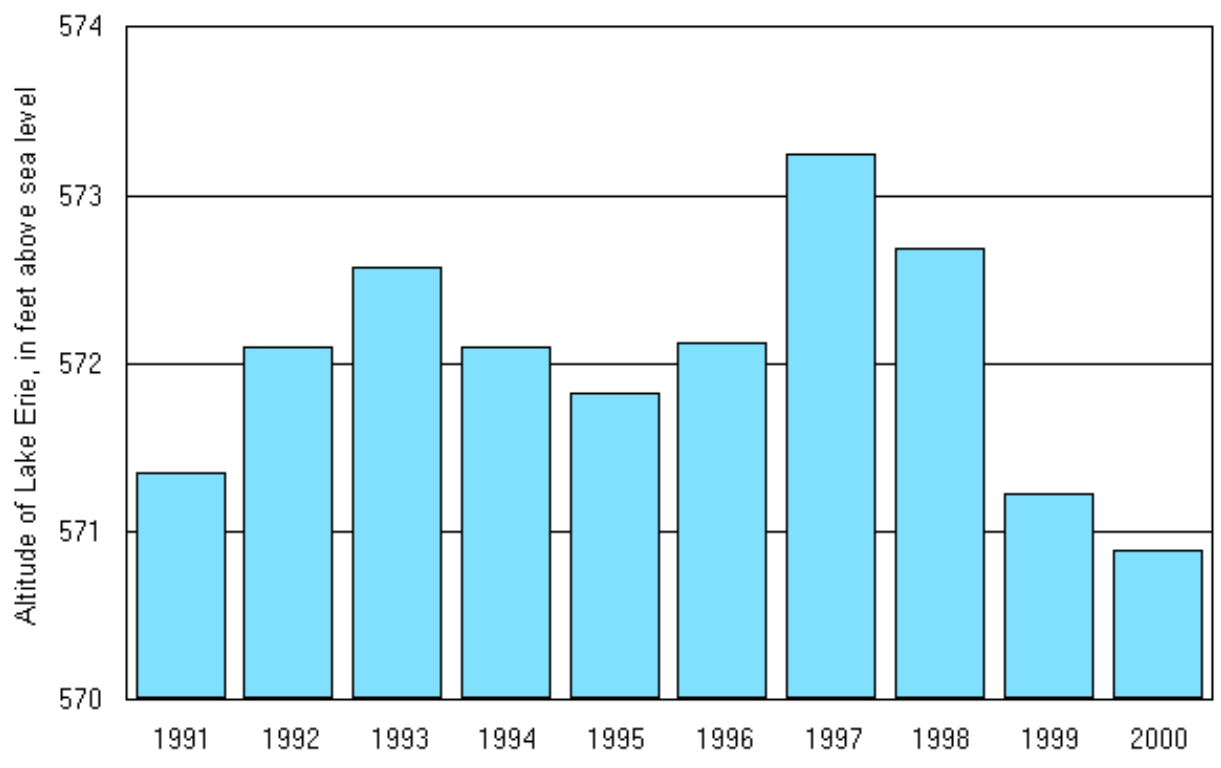

Figure 1. Level of Lake Erie, 1991-2000.

\section{Precipitation at Monroe}

Precipitation at Monroe did not have an upward or downward trend from 1991 to 2000 (fig. 2). Annual precipitation was above the long-term average of 31 inches for 7 years and below average for 3 years (National Oceanic and Atmospheric Administration, written communication, 2001). Data from 2001 are not available.

Annual precipitation may not be an accurate indicator of recharge to the ground-water flow system. In Michigan, most recharge typically occurs between the first hard frost in the fall and the 
beginning of the growing season in the spring. Precipitation during this recharge period was lower from 1996 to 2000 than in any of the previous five years, except 1994. The recharge period was calculated from October of a year through April of the following year. Thus, the 1991 recharge period is October 1991 through April 1992.

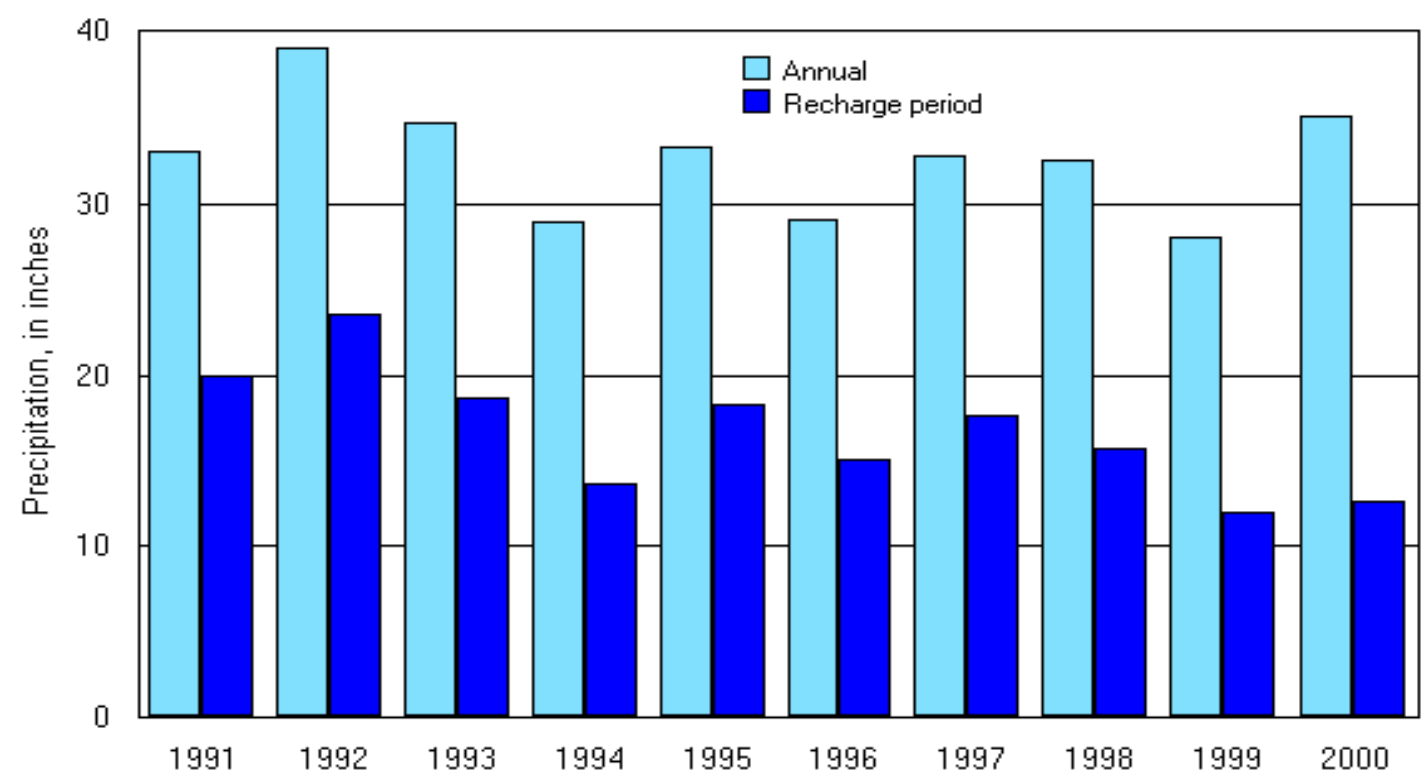

Figure 2. Precipitation at city of Monroe, 1991-2000.

\section{Streamflow in River Raisin at Manchester}

Streamflow during sustained periods with no rainfall did not have an upward or downward trend from 1991 to 2000 (fig. 3). The 7-day minimum flow is defined as the lowest mean value for

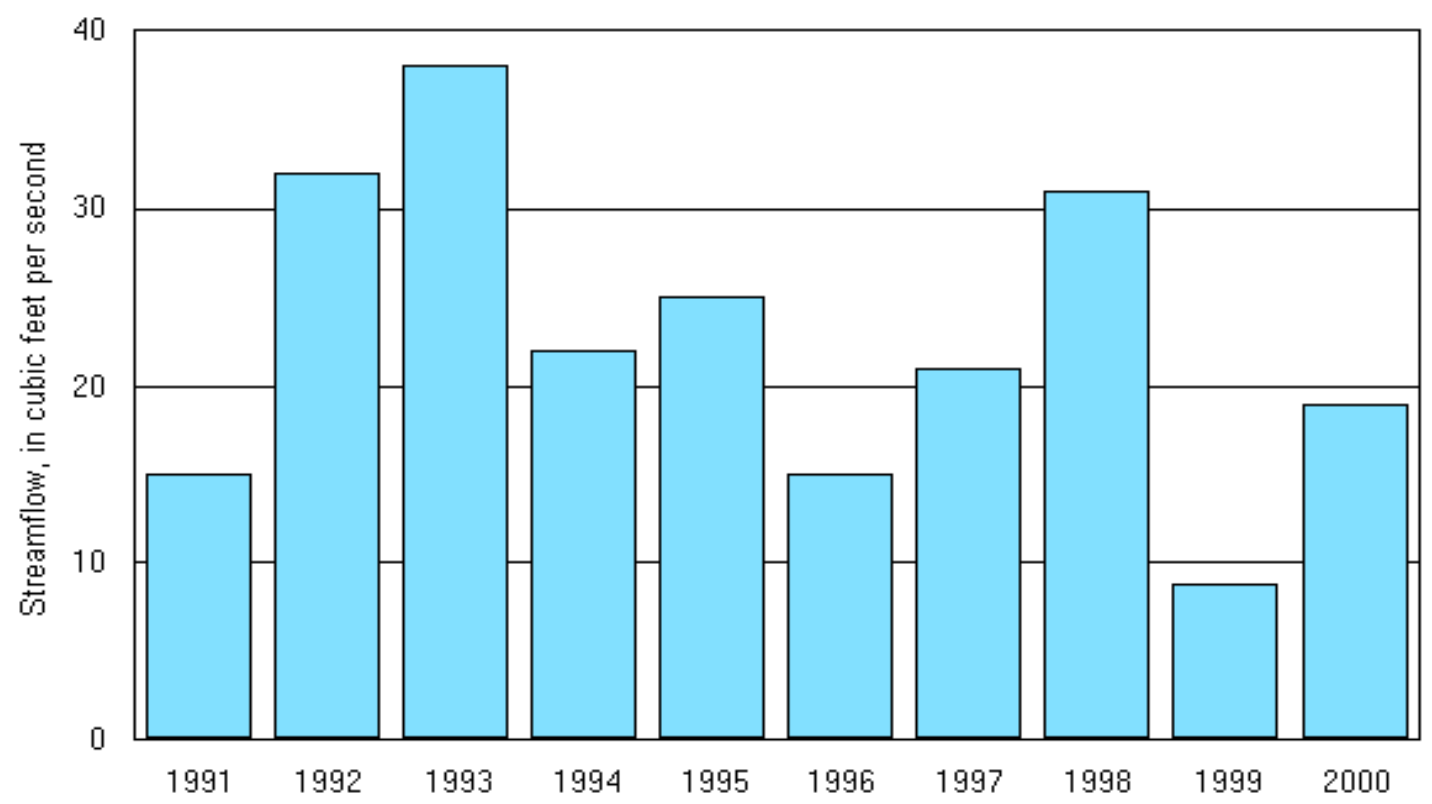

Figure 3. Seven-day minimum flows in the River Raisin at Manchester, 1991-2000. 
any 7-consecutive-day period in a year. This streamflow statistic can be viewed as an indicator of ground-water discharge to streams. Thus trends in this statistic, in areas largely unaffected by human activities, can be indicative of climatic trends in ground-water levels. The watershed upstream of the gage at Manchester does not have significant urbanization or large ground-water withdrawals.

\section{Ground-Water Use}

\section{Quarry dewatering}

The amount of water withdrawn for quarry dewatering has more than doubled since 1991. Quarry dewatering is the largest ground-water use in Monroe County. About 20 Mgd (million gallons per day) were withdrawn in 2000 - this is about 75 percent of the total ground-water withdrawals for the County (fig. 4). Withdrawals were 9, 14, 18, and $20 \mathrm{Mgd}$ in 1991, 1996, 1999, and 2000 , respectively.

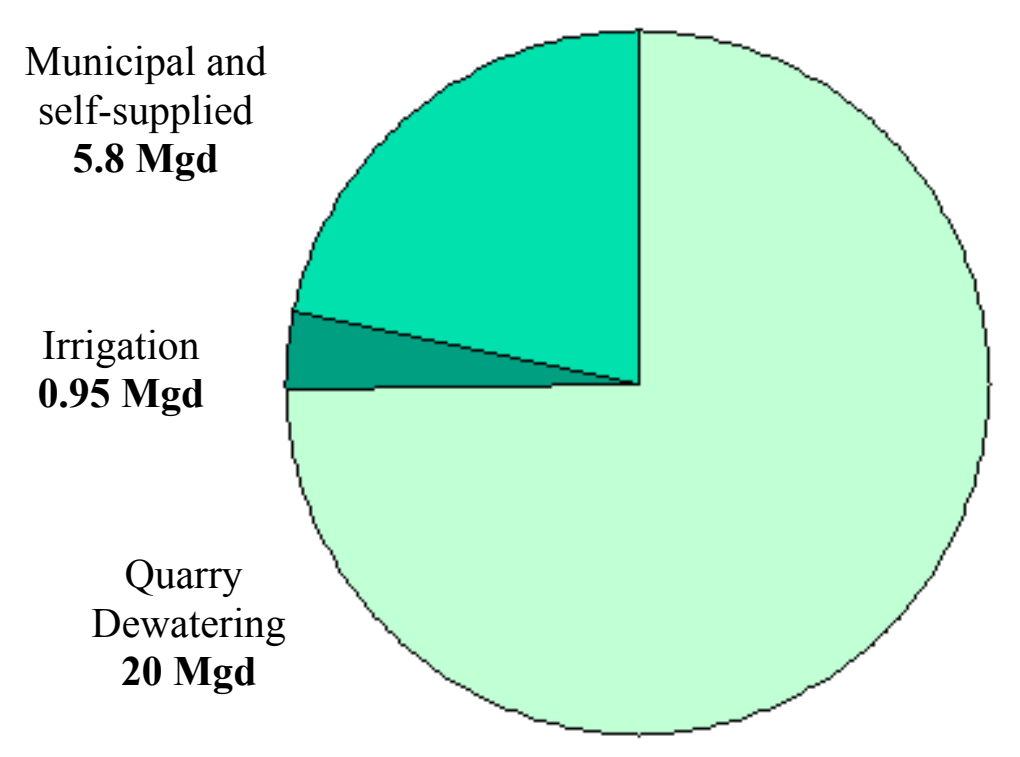

Figure 4. Estimated ground-water use in 2000.

Withdrawals from quarries are reported by the quarry owners to MDEQ as part of the permitting process for discharge to streams. The USGS measured the discharge from one of the largest dewatering operations, London Aggregates, in October, November and December 2001 on the North Branch Amos Palmer Drain at Grames Road. The measured discharges, 9.0, 7.8, and 7.9 Mgd are similar to the reported discharges from London Aggregates in 1999 and 2000 (Ms. Jennifer Rogers, MDEQ, written communication, 2001).

Currently there are reported to be 8 active quarries in Monroe County, up from 6 in 1991. In addition there are quarries with dewatering operations adjacent to Monroe County in Wayne County, Michigan and Lucas County, Ohio.

\section{Irrigation}

Ground-water withdrawals for irrigation are not measured in Michigan, however, a rough estimate indicates an increase in withdrawals. The number of farms that use irrigation and the number of acres in each farm are reported by USDA (U.S. Department of Agriculture), however 
the amount of water withdrawn and the source of the water (ground water or surface water) are not reported. In 1992, 64 farms irrigated 2385 acres; in 1997, 79 farms irrigated 5047 acres (USDA, 1999).

MDEQ, in cooperation with Michigan State University, has developed a model that estimates water use for irrigation in Michigan. The model estimates that about $2 \mathrm{Mgd}$ were applied to the irrigated acreage in 1997. The Agricultural Extension office in Monroe County, estimates that about 25 percent of irrigation is from ground water. (Mr. Ron Van Til, MDEQ, personal communication, 2001). Thus, about 0.49 Mgd of ground water were used for irrigation in 1997.

Ground-water withdrawals for golf-course irrigation are not measured in Michigan. Since 1997, however, golf courses that have the capacity to withdraw over $0.1 \mathrm{Mgd}$ for any 30-day period have been required to report usage to MDEQ. In 1997, 7 courses irrigated with 0.29 Mgd of ground water and $0.15 \mathrm{Mgd}$ of surface water. In 1999, 11 courses irrigated with $0.46 \mathrm{Mgd}$ of ground water and 0.58 of surface water (Mr. Ron Van Til, MDEQ, written communication, 2001). Data after 1999 are not available yet, but the number of courses in Monroe County is about 30.

\section{Municipal and self-supplied}

Municipal ground-water withdrawals are measured in Michigan; self-supplied withdrawals are not. Trends are difficult to determine due to changes in methods of estimating water use.The USGS and MDEQ cooperatively estimate these water uses on a five-year cycle. In Monroe County, municipal ground-water withdrawals were estimated to be $0.13,0.14$ and $0.58 \mathrm{Mgd}$ in 1985, 1990, and 1995, respectively. Self-supplied commercial/industrial ground-water withdrawals were estimated to be $0.47,0.48$, and $0.29 \mathrm{Mgd}$ for the same 3 years. Self-supplied domestic ground-water withdrawals were estimated to be $2.90,2.90$, and $4.88 \mathrm{Mgd}$. The total municipal and self-supplied ground-water withdrawals for Monroe County are 3.50, 3.52, and 5.75 Mgd for 1985, 1990, and 1995, respectively (Ms. Carol Luukkonen, USGS, written communication, 2001).

\section{Ground-Water Levels}

From December 1991 to December 2001, ground-water levels declined in 24 of 31 USGS observation wells (fig. 5 MAP and BAR for this period on next page). Water-level declines were 10 feet or more in 17 wells. The average for 31 wells is a decline of 12 feet. The maximum decline was 80 feet in G17, which is adjacent to Hanson Aggregates quarry. Water levels in G28 increased 13 feet, however, this well is in a karst area and water levels in the well may change more than 30 feet in a year in response to recharge events, such as the record high October 2001 rainfall. The largest declines are in the northwestern townships, except for the decline in G17. G10, the northwestern most well, did not have a large decline, however, it is the only observation well completed in glacial deposits. All other observation wells are open to one or more bedrock aquifers.

The amount of calculated decline is dependent upon the period of record chosen for comparison. For instance, if the period 1993 to 1999 is used, water levels declined in all wells, with an average decline of 17 feet. Comparison of all water levels to their initial measurement, however, clearly demonstrates the downward trend of ground-water levels in Monroe County from 1991 to 2001 (fig 6). 


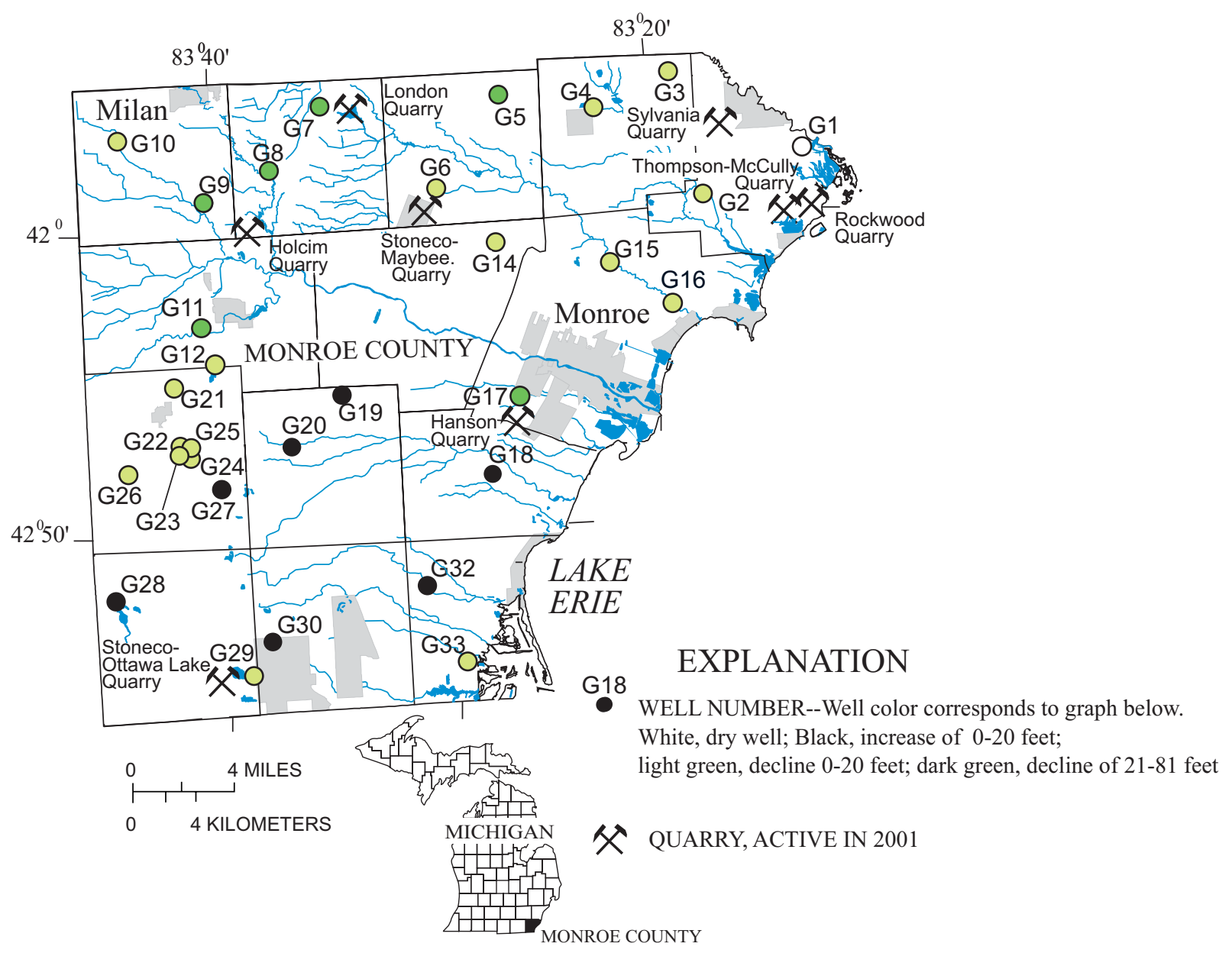

WELL NUMBER

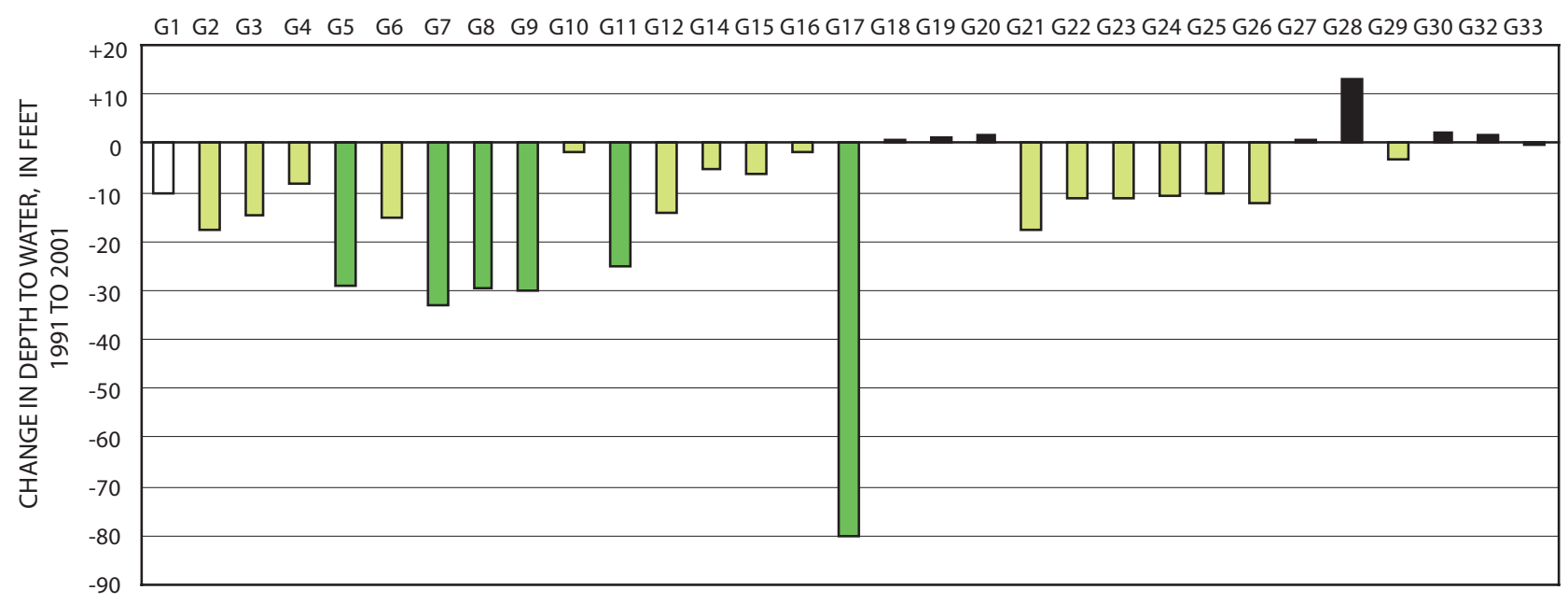

Figure 5. Location of observation wells and active quarries in Monroe County, Michigan, and change in depth to water from $1991-2001$. 


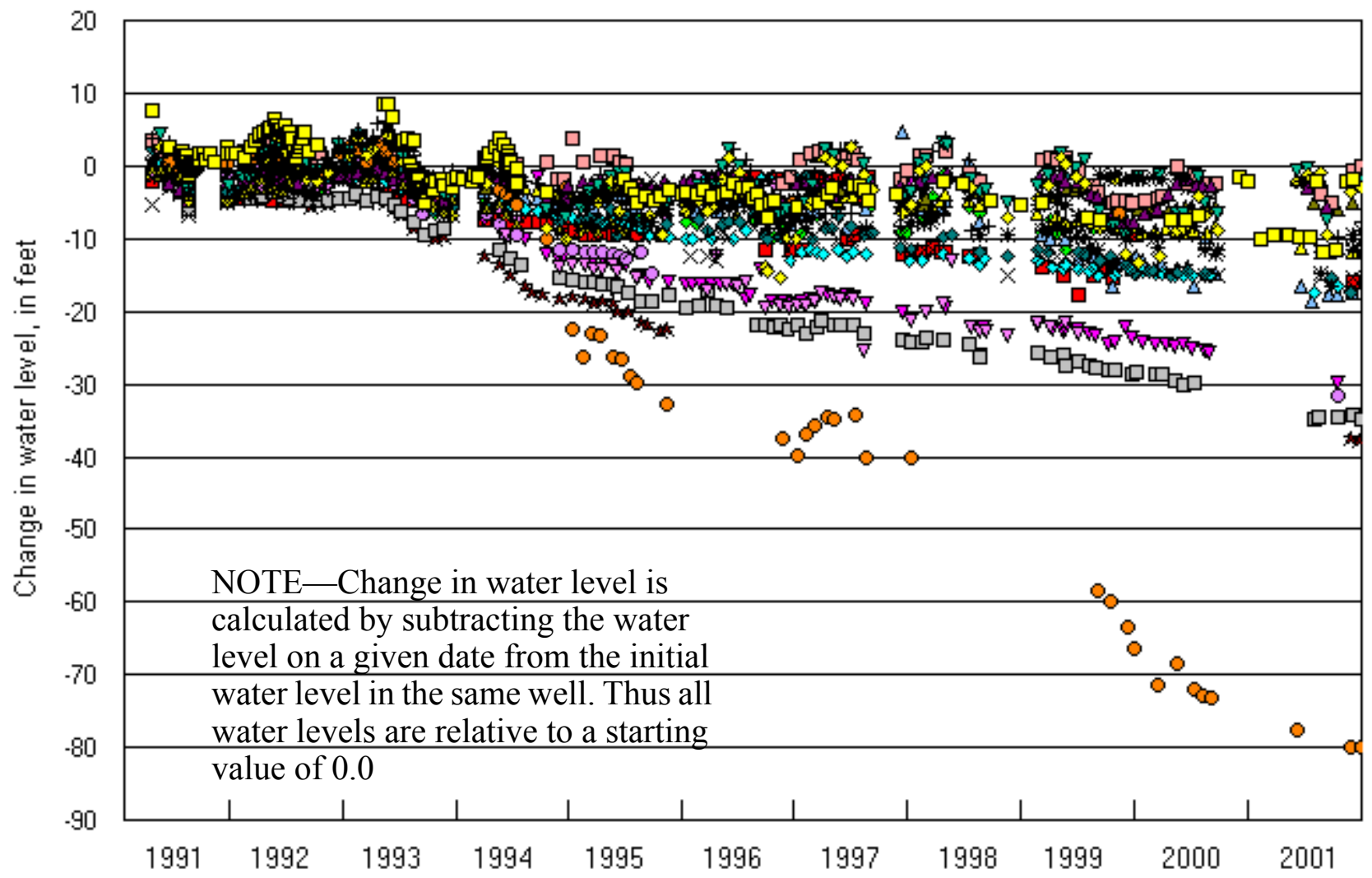

Figure 6. Changes in water levels in USGS observation wells, from initial measurement through 2001.

Long-term records from GLTO (located near G23) show that ground-water levels have been declining since recording began in 1979 (fig. 7). The rate of decline from 1998 through 2001 is greater than for the earlier period of record. This long-term decline is likely caused by groundwater withdrawals, although a decrease in recharge is possible (Nicholas and others, 1996).

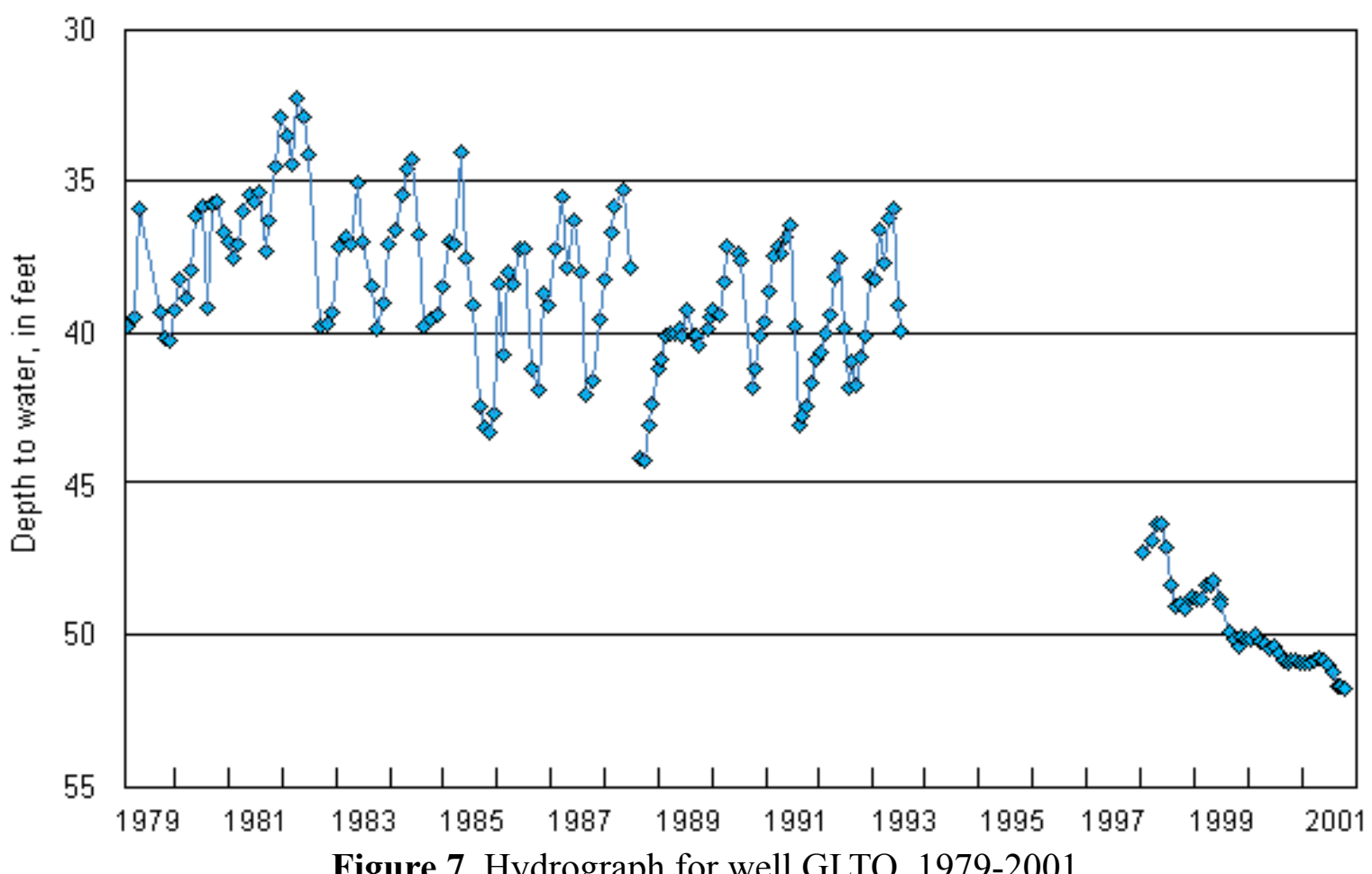


Water levels in GLTO and G7 have very similar responses to stresses, although the two wells are about 12 miles apart (fig. 8). For example, the sharp decline of about 0.5 feet in G7 on December 14 is mirrored by a decline of about 0.4 feet in GLTO. These similar responses are probably caused by the same withdrawal, indicating that (1) the aquifer at G7 has excellent hydraulic connection to the aquifer at GLTO, and (2) stresses in the aquifer are transmitted rapidly and over large distances. These responses are common in fractured carbonate aquifers (Nicholas and others, 1996).

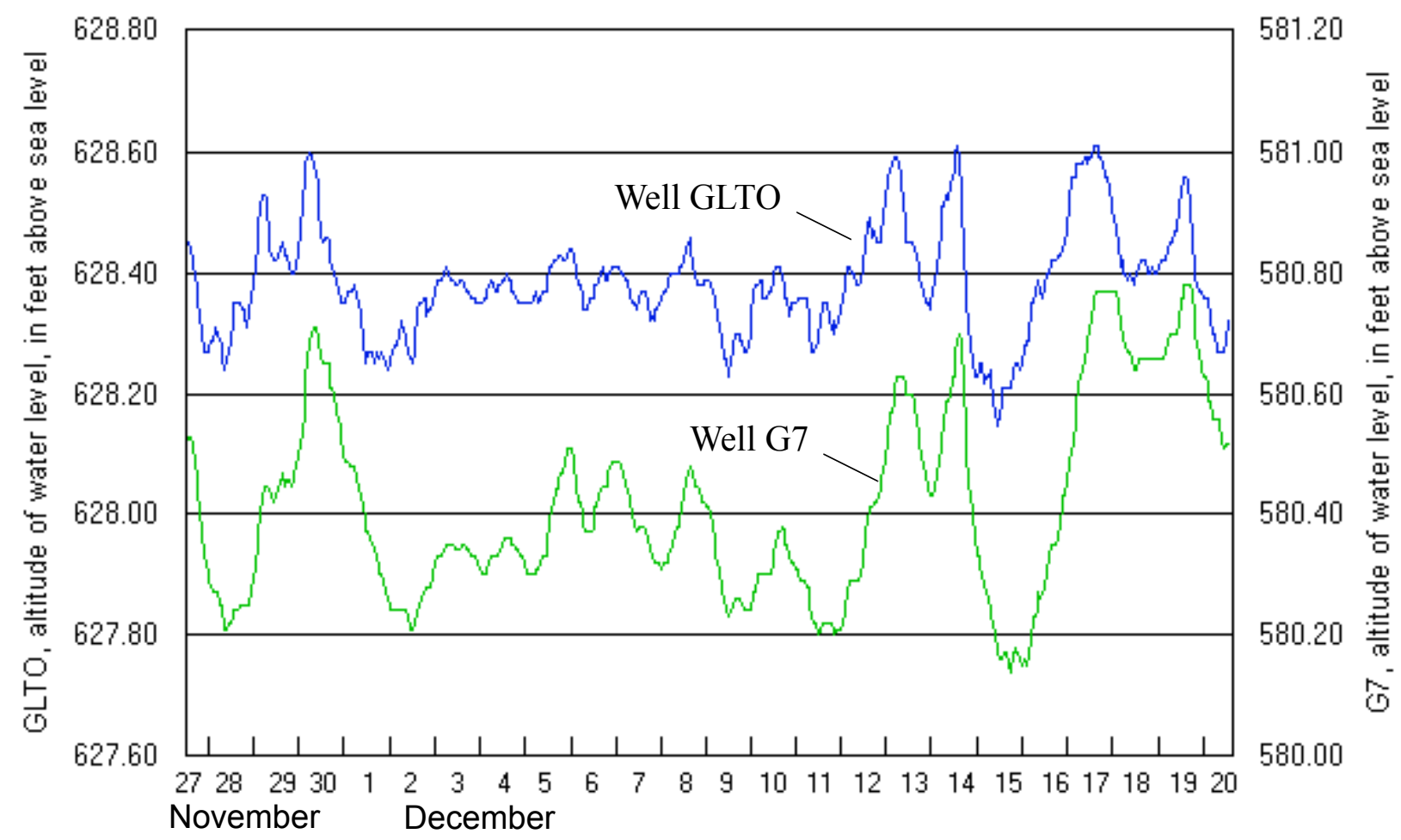

Figure 8. Hydrographs for wells GLTO and G7, November 27 to December 20, 2001.

\section{Ground-Water Quality}

Ground-water quality did not change significantly from 1991 to 2001. Samples were collected from 14 USGS observation wells in November 2001; these same wells were sampled in 1991 or 1992 by the USGS.

Several physical and chemical properties were analyzed in 2001, including specific conductance, $\mathrm{pH}$, and major ions. Specific conductance can be an indicator of changes in water quality, since it typically has a strong relationship to dissolved solids. For the 14 wells that were sampled in 2001, specific conductance declined in 6 wells, increased in 7 wells, and did not change in one well (table 1). 


\section{SUMMARY}

During the past decade, ground-water levels have declined in bedrocks aquifers throughout most of Monroe County. The declines are greatest in the northwestern townships. From 1991 to 2001, ground-water levels declined 10 feet or more in 17 USGS observation wells. The water level in one well declined 80 feet.

Available hydrologic data that can indicate trends in climate are Lake Erie levels, precipitation at Monroe, and River Raisin streamflow. None of these data show a trend during the past decade.

Ground-water use has increased substantially in Monroe County during the past decade. The largest use is quarry dewatering operations. The amount of ground-water withdrawn by quarries has doubled during the past decade and is about 75 percent of the total ground-water use in the County.

\section{REFERENCES}

National Oceanic and Atmospheric Administration National Climatic Data Center, 1991-2000, Climatological data annual summary Michigan: v.106-115, 25 p. (one report per year)

Nicholas, J.R., Rowe, G.L., and Brannen, J.R., 1996, Hydrology, water quality, and effects of drought in Monroe County, Michigan: U. S. Geological Survey Water-Resources Investigations Report 94-4161, $169 \mathrm{p}$.

Sherzer, W.H., 1900, Geological report on Monroe County: Geological Survey of Michigan, v.7, part 1.

U.S. Army Corps of Engineers, Detroit District, 1991-2001, Monthly bulletin of lake levels for the Great Lakes: 4 p. (one report per month)

U.S. Department of Agriculture, National Agricultural Statistics Service, 1999, Census of agriculture-Michigan state and county data: v.1 part 22, $512 \mathrm{p}$. 
Table 1. Chemical and physical characteristics of ground water in Monroe County,

Michigan, 1991-92 and 2001

[1991-92 analyses by U.S. Geological Survey; 2001 analyses by Michigan Department of Environmental Quality] $\left[\mu \mathrm{S} / \mathrm{cm}\right.$, microsiemens per centimeter at 25 degrees Celsius; ${ }^{\circ} \mathrm{C}$, degrees Celsius; mg/L, milligrams per liter; ND, no data available]

\begin{tabular}{|c|c|c|c|c|c|c|c|c|c|c|c|c|c|}
\hline $\begin{array}{l}\text { Well } \\
\text { identifier }\end{array}$ & Date & $\begin{array}{l}\text { Specific } \\
\text { conductance, } \\
(\mu \mathrm{S} / \mathrm{cm})\end{array}$ & $\begin{array}{l}\mathrm{pH} \\
\text { (standard } \\
\text { units) }\end{array}$ & $\begin{array}{l}\text { Hardness } \\
\text { total }(\mathrm{mg} / \mathrm{L} \\
\left.\text { as } \mathrm{CaCO}_{3}\right)\end{array}$ & $\begin{array}{l}\text { Alkalinity } \\
(\mathrm{mg} / \mathrm{L} \text { as } \\
\left.\mathrm{CaCO}_{3}\right)\end{array}$ & $\begin{array}{l}\text { Calcium, } \\
\text { dissolved } \\
(\mathrm{mg} / \mathrm{L} \text { as } \\
\mathrm{Ca})\end{array}$ & $\begin{array}{l}\text { Magnesium, } \\
\text { dissolved } \\
(\mathrm{mg} / \mathrm{L} \text { as } \\
\mathrm{Mg})\end{array}$ & $\begin{array}{l}\text { Sodium, } \\
\text { dissolved } \\
(\mathrm{mg} / \mathrm{L} \text { as } \\
\mathrm{Na})\end{array}$ & $\begin{array}{l}\text { Potassium, } \\
\text { dissolved } \\
(\mathrm{mg} / \mathrm{L} \text { as } \\
\mathrm{K})\end{array}$ & $\begin{array}{l}\text { Sulfate, } \\
\text { dissolved } \\
(\mathrm{mg} / \mathrm{L} \text { as } \\
\left.\mathrm{SO}_{4}\right)\end{array}$ & $\begin{array}{l}\text { Chloride, } \\
\text { dissolved } \\
(\mathrm{mg} / \mathrm{L} \text { as } \\
\mathrm{Cl})\end{array}$ & $\begin{array}{l}\text { Fluoride, } \\
\text { dissolved } \\
\text { (mg/L as } \\
\text { F) }\end{array}$ & $\begin{array}{l}\text { Silica, } \\
\text { dissolved } \\
(\mathrm{mg} / \mathrm{L} \text { as } \\
\left.\mathrm{SiO}_{2}\right)\end{array}$ \\
\hline \multirow[t]{2}{*}{ G3 } & $05-05-92$ & 2,380 & 7.1 & 1,500 & 184 & 410 & 110 & 46 & 5.3 & 1,200 & 43 & 1.7 & 15 \\
\hline & $11-08-01$ & 2,420 & 7.1 & 1,287 & 201 & 433 & 124 & 48 & 3.9 & 1,208 & 33 & 1.4 & 16.3 \\
\hline \multirow[t]{2}{*}{ G4 } & $11-05-91$ & 3,900 & 7.0 & 1,800 & 172 & 460 & 150 & 250 & 9.8 & 1,100 & 600 & .90 & 16 \\
\hline & $11-08-01$ & 3,890 & 7.1 & 1,573 & 205 & 168 & 168 & 249 & 10.2 & 1,086 & 611 & 1.1 & 20 \\
\hline \multirow[t]{2}{*}{ G6 } & $05-05-92$ & 1,230 & 7.6 & 640 & 220 & 140 & 66 & 17 & 3.1 & 410 & 8.6 & 1.0 & 18 \\
\hline & $11-07-01$ & 1,280 & 7.2 & 711 & 314 & 152 & 79 & 37 & 3.1 & 377 & 110 & 1.2 & 16 \\
\hline \multirow[t]{2}{*}{ G7 } & $11-04-91$ & 344 & 7.7 & 110 & 189 & 29 & 9.8 & 31 & 1.0 & 0.20 & 2.6 & 1.2 & 13 \\
\hline & $11-08-01$ & 420 & 7.6 & 111 & 206 & 33 & 12 & 32 & 1.1 & 7 & ND & 1.5 & 14 \\
\hline \multirow[t]{2}{*}{ G8 } & 11-04-91 & 523 & 7.4 & 220 & 288 & 52 & 21 & 34 & 1.7 & 2.5 & 3.6 & 1.5 & 9.5 \\
\hline & $11-13-01$ & 530 & 6.9 & 212 & 292 & 35 & 26 & 34 & 1.2 & 6 & ND & 1.6 & 9.0 \\
\hline \multirow[t]{2}{*}{ G12 } & $01-23-92$ & 462 & 7.6 & 230 & 236 & 54 & 20 & 12 & 1.1 & 3.1 & 13 & 1.1 & 15 \\
\hline & $11-07-01$ & 450 & 7.5 & 206 & 227 & 48 & 23 & 12.2 & 1.1 & 5 & 4 & 1 & 16.6 \\
\hline \multirow[t]{2}{*}{ G15 } & $11-05-91$ & 1,460 & 7.2 & 850 & 225 & 230 & 63 & 7.4 & 2.7 & 630 & 22 & .5 & 10 \\
\hline & $11-08-01$ & 1,490 & 7.2 & 821 & 314 & 226 & 63 & 34 & 2.9 & 409 & 74 & .8 & 12.7 \\
\hline \multirow[t]{2}{*}{ G16 } & $04-28-92$ & 2,550 & 7.1 & 1,700 & 226 & 410 & 160 & 18 & 4.6 & 1,400 & 22 & .90 & 13 \\
\hline & $11-08-01$ & 2,440 & 7.1 & 1,409 & 222 & 402 & 165 & 19 & 4.8 & 1,237 & 11 & .6 & 16.2 \\
\hline \multirow[t]{2}{*}{ G17 } & $05-20-92$ & 2,310 & 7.3 & 1,500 & 172 & 380 & 120 & 23 & 2.5 & 1,200 & 36 & 1.0 & 13 \\
\hline & $11-13-01$ & 2,390 & 6.9 & 1,537 & 210 & 420 & 137 & 19 & 2.7 & 1,206 & 31 & .6 & 15 \\
\hline
\end{tabular}


Table 1. Chemical and physical characteristics of ground water in Monroe County, Michigan, 1991-92 and 2001--Continued

[1991-92 analyses by U.S. Geological Survey; 2001 analyses by Michigan Department of Environmental Quality] $\left[\mu \mathrm{S} / \mathrm{cm}\right.$, microsiemens per centimeter at 25 degrees Celsius; ${ }^{\circ} \mathrm{C}$, degrees Celsius; $\mathrm{mg} / \mathrm{L}$, milligrams per liter; ND, no data avilable]

\begin{tabular}{|c|c|c|c|c|c|c|c|c|c|c|c|c|c|}
\hline $\begin{array}{l}\text { Well } \\
\text { identifier }\end{array}$ & Date & $\begin{array}{l}\text { Specific } \\
\text { conductance, } \\
(\mu \mathrm{S} / \mathrm{cm})\end{array}$ & $\begin{array}{l}\mathrm{pH} \\
\text { (standard } \\
\text { units) }\end{array}$ & $\begin{array}{l}\text { Hardness } \\
\text { total }(\mathrm{mg} / \mathrm{L} \\
\left.\text { as } \mathrm{CaCO}_{3}\right)\end{array}$ & $\begin{array}{l}\text { Alkalinity } \\
(\mathrm{mg} / \mathrm{L} \text { as } \\
\left.\mathrm{CaCO}_{4}\right)\end{array}$ & $\begin{array}{l}\text { Calcium, } \\
\text { dissolved } \\
\text { (mg/L as } \\
\mathrm{Ca})\end{array}$ & $\begin{array}{l}\text { Magnesium, } \\
\text { dissolved } \\
(\mathrm{mg} / \mathrm{L} \text { as } \\
\mathrm{Mg})\end{array}$ & $\begin{array}{l}\text { Sodium, } \\
\text { dissolved } \\
(\mathrm{mg} / \mathrm{L} \text { as } \\
\mathrm{Na})\end{array}$ & $\begin{array}{l}\text { Potassium, } \\
\text { dissolved } \\
(\mathrm{mg} / \mathrm{L} \text { as } \\
\mathrm{K}) \\
\end{array}$ & $\begin{array}{l}\text { Sulfate, } \\
\text { dissolved } \\
(\mathrm{mg} / \mathrm{L} \text { as } \\
\left.\mathrm{SO}_{4}\right)\end{array}$ & $\begin{array}{l}\text { Chloride, } \\
\text { dissolved } \\
(\mathrm{mg} / \mathrm{L} \text { as } \\
\mathrm{Cl})\end{array}$ & $\begin{array}{l}\text { Fluoride, } \\
\text { dissolved } \\
\text { (mg/L as } \\
\mathrm{F})\end{array}$ & $\begin{array}{l}\text { Silica, } \\
\text { dissolved } \\
(\mathrm{mg} / \mathrm{L} \text { as } \\
\left.\mathrm{SiO}_{2}\right)\end{array}$ \\
\hline \multirow{2}{*}{ G18 } & $01-23-92$ & 694 & 7.4 & 370 & 342 & 85 & 25 & 8.6 & 2.2 & 48 & 3.9 & 1.0 & 12 \\
\hline & $11-07-01$ & 700 & 7.2 & 362 & 331 & 80 & 28 & 8.1 & 2.1 & 41 & ND & .9 & 14.2 \\
\hline \multirow[t]{2}{*}{ G20 } & $01-23-92$ & 783 & 7.4 & 380 & 222 & 120 & 16 & 22 & 1.1 & 110 & 62 & .60 & 18 \\
\hline & $11-07-01$ & 560 & 7.2 & 261 & 196 & 84 & 12 & 11.3 & .9 & 54 & 19 & .7 & 20.5 \\
\hline \multirow[t]{2}{*}{ G28 } & $10-29-91$ & 1,140 & 7.0 & 450 & 255 & 120 & 32 & 52 & 3.2 & 110 & 150 & .50 & 6.3 \\
\hline & $11-07-01$ & 1,080 & 7.0 & 501 & 321 & 167 & 38 & 46 & 3.4 & 102 & 103 & .5 & 8.2 \\
\hline \multirow[t]{2}{*}{ G29 } & $10-29-91$ & 519 & 7.6 & 250 & 197 & 63 & 20 & 4.9 & .90 & 43 & 12 & .90 & 10 \\
\hline & $11-07-01$ & 520 & 7.3 & 261 & 208 & 66 & 24 & 4.8 & 1.0 & 46 & 10 & 1 & 11.7 \\
\hline \multirow[t]{2}{*}{ G32 } & 04-28-92 & 2,200 & 7.2 & 1,400 & 197 & 390 & 110 & 6.0 & 2.4 & 1,100 & 11 & 1.6 & 12 \\
\hline & $11-07-01$ & 2,120 & 7.1 & 1,275 & 199 & 389 & 129 & 6.0 & 2.4 & 1,105 & 6 & 1.5 & 13.5 \\
\hline
\end{tabular}


APPENDIX —Period of Record Hydrographs for USGS Observation Wells in Monroe County. 